\section{Revised criteria for the assessment and interpretation of occlusal deviations in the deciduous dentition: a public health perspective}

\author{
Critérios para a determinação e interpretação de \\ desvios oclusais na dentição decídua: uma \\ perspectiva de saúde pública
}

\footnotetext{
${ }^{1}$ Faculdade de Saúde Pública, Universidade de São Paulo, São Paulo, Brasil. 2 Programa de Pós-Graduação em Saúde Pública, Universidade Católica de Santos, São Paulo, Brasil. 3 Faculdade de Odontologia Universidade de São Paulo, São Paulo, Brasil.

Correspondence E. R. Almeida Departamento de Prática de Saúde Pública, Faculdade de Saúde Pública, Universidade de São Paulo. Av. Dr. Arnaldo 715, São Paulo, SP 01246-904, Brasil. eralmeida@usp.br
}

\begin{abstract}
Secondary data from a randomized sample of Brazilian preschool children were analyzed to evaluate the prevalence of occlusal deviations in the deciduous dentition that can adversely affect the permanent dentition, using revised criteria. Overjet and overbite used cut-off points described in the literature to exclude mild malocclusion cases. Overjet $>3 \mathrm{~mm}$ and overbite $>$ $3 \mathrm{~mm}$ were present in $16 \%$ and $7 \%$ of the children, respectively. On the sagittal plane, only bilateral deviations were considered: molar relationship in distal step (9.7\%) and mesial step (6\%) and canine relationship class 2 (11\%) and class 3 (2.9\%). Regarding other occlusal deviations, severity criteria were not reported in the literature. Crude prevalence rates of openbite (27.9\%), posterior crossbite (11.3\%), and crowding in the maxillary arch (7\%) and mandibular arch (11.3\%) were recorded. The assessment of malocclusion in the deciduous dentition should focus on the severity of occlusal deviations for the identification of cases and non-cases that are relevant to public health. Need for further consensus and improvement in the interpretation of epidemiological data on malocclusion related to this developmental stage is emphasized.
\end{abstract}

Dental Occlusion; Primary Dentition; Oral Health
Eliete Rodrigues de Almeida 1

Paulo Capel Narvai 1

Paulo Frazão 2

Antonio Carlos Guedes-Pinto ${ }^{3}$

\section{Introduction}

Occlusal traits in the deciduous dentition 1,2,3,4,5,6 and the characteristics that adversely affect the permanent dentition and result in malocclusion $5,7,8,9,10,11,12,13$ have been investigated. Foster \& Hamilton 2 reported the wide variety of occlusal conditions in the deciduous dentition, which appears to indicate that these are not fixed but flexible attributes ${ }^{14}$ whose aspects should be considered in epidemiological investigations.

Despite high malocclusion prevalence described in recent studies conducted in both developed and developing countries $7,8,9$, nearly all have monotonously repeated the existence of a wide variation in prevalence values $(\sim 5 \%$ to $\sim 85 \%$ ), depending on the interpretation of what constitutes malocclusion.

Part of this variation during the early stages of occlusal development cannot be attributed solely to interaction between genetic background and environmental factors acting during growth and development of the dental occlusion 15,16,17,18,19, but is due to differences in the criteria for interpreting relevant occlusal deviations 11,20.

Although such criteria are necessarily arbitrary to some extent, they can provide a meaningful basis for recording methods, which can in turn be applied to comparative epidemiological studies in different populations and to the investigation of interrelationships between the various traits 20 . 
Considered separately or as a whole, these aspects have pointed to the importance of a broad consensus on interpretation of malocclusion severity in the deciduous dentition and the identification of cases and non-cases.

From a public health perspective, efforts could provide information for the implementation of general and specific measures for prevention of malocclusion 21 and reduction of socially unacceptable malocclusions 7 .

This study aimed to evaluate occlusal deviations in the deciduous dentition that can adversely affect the permanent dentition, using revised criteria for the assessment and interpretation of prevalence values. Secondary data from a randomized sample of a cross-sectional study on Brazilian preschool children were analyzed 22 .

\section{Methods}

\section{Study design}

Part of the wide variation in malocclusion prevalence in the deciduous dentition results from differences in the interpretation of what constitutes a malocclusion 23 . The plasticity of the growth and developmental process of the orofacial complex during this phase of the life cycle is remarkable 24 . There is a need for a more comprehensive and rigorous assessment of the clinical dimension, based on sound concepts of occlusal development, taking into account the issue of relevance for public health policymakers 25 .

Based on this theoretical framework, a literature review of occlusal traits that can adversely affect the permanent dentition (and thus of the criteria employed for interpretation of data on occlusal deviations in the deciduous dentition) was carried out. This systematized information was used to analyze secondary data from a crosssectional study on Brazilian preschool children conducted in Mauá 22, a municipality located in Greater Metropolitan São Paulo, where a public oral health program had been implemented for pregnant women and preschoolers (http:www. maua.sp.gov.br; accessed on 11/Oct/2006).

\section{Data source}

Children from three to five years old were randomly selected from a list of 3,409 children enrolled in public (municipal) and private preschools in 2001. The projected sample size was based on a prevalence of malocclusion in the deciduous dentition of approximately $50 \%$, with $5 \%$ sample error, $95 \%$ confidence level, and a $20 \%$ non-res- ponse rate. Four hundred and sixty-eight children were called for the dental examinations, 156 for each year of age 26 . A total of 385 children (82.3\%) were examined.

In order to evaluate the occlusal traits in the deciduous dentition, only children with complete deciduous dentition and no permanent teeth erupted were considered eligible for the sub-sample 27 . Likewise, to eliminate potential biases, children with exfoliated deciduous teeth and with partially or totally erupted permanent teeth - which correspond to a later stage of occlusal development - were excluded from the study. The final sub-sample consisted of 344 preschoolers.

Five calibrated dentists conducted the examinations in the preschoolers under natural light, using CPI probes (ball point) 28 , wooden spatulas, and buccal mirrors. Occlusion was observed in maximum intercuspal relationship, and data were recorded on charts especially developed for the study 22 .

Sagittal relationship of dental arches was determined from the relationships of the second deciduous molars and canines as classified according to Baume ${ }^{1}$ and Foster \& Hamilton 2 , respectively. The molar relationship was classified in straight terminal plane, when the terminal plane of the second deciduous molars was flush, distal, or mesial, according to the distal or mesial step terminally. The canine relationship was denoted Class 1 if the tip of the maxillary canine occluded in the embrasure of the mandibular canine and first molar, Class 2 if the tip of the maxillary canine was anterior to Class 1 , and Class 3 if it was posterior to Class 1 . The molar and canine relationships were recorded separately on both sides. Prevalence rates were defined considering bilateral deviations.

Posterior crossbites were also classified according to Foster \& Hamilton 2. Unilateral and bilateral posterior crossbites were recorded in the presence of one or more buccally or lingually displaced/occluding teeth in the posterior segment (deciduous molars) on one or both sides, respectively.

Maxillary and mandibular overjet, overbite, and openbite were assessed using a CPI probe 28 in millimeter measurements.

Overjet was defined as horizontal overlap of the incisors and was positive if the upper incisor was ahead of the lower incisor and negative if the lower incisor was in front of the upper incisor (mandibular overjet), and was assessed using the probe from the labial surface of the most anterior lower central incisor to the labial surface of the most anterior upper central incisor, parallel to the occlusal plane. 
Overbite was considered as the vertical overlap of the incisors when the posterior teeth were in contact, classified as positive if the incisors overlapped vertically and negative - defined as openbite - if they were vertically separated. If an openbite was present, a single measurement was performed between the edge of the lower central incisor and that of the upper central incisor.

Crowding and spacing were assessed qualitatively (presence/absence) by registering overlapping teeth or interdental spaces, as proposed by Baume 1. Type I and II arches were characterized as the presence or absence of generalized interdental spaces, respectively.

Examiners were subjected to calibration. During data collection, $9.1 \%$ of the sample was reexamined and the intra-examiner error was also measured, as recommended by WHO 28 . Kappa coefficient 29 was adopted to assess the examiners' reproducibility for each occlusal trait. During calibration, all outcomes showed kappa $\geq$ 0.61 except the molar relationship (0.60) and kappa between 0.61 and 1.00 during data collection. Therefore, the resulting data were considered reliable for the proposed analysis in this study.

\section{Analysis}

Analyzed data and tabular presentation were obtained using SPSS 11.0 software (SPSS Inc., Chicago, USA).

\section{Results}

Data from the study conducted in Mauá showed a sub-sample of 344 preschool children, $51.7 \%$ boys and $48.3 \%$ girls (mean age $=3.94$; median $=$ 4.00).

Frequencies and proportions of molar and canine relationships were analyzed. Values on the diagonals correspond to the number of cases with identical conditions on the right and left sides. Comparing these values by referenced teeth and between sides, the results showed a strong similarity in sagittal intermaxillary relationships (Table 1). Considering values from both sides, the relationships of the second deciduous molars were straight terminal plane $84.3 \%$, distal step $9.7 \%$, and mesial step $6 \%$. The frequencies of Class 1, 2, and 3 canine relationships were $86 \%$,

Distribution of molar and canine relationships in a sample of preschoolers. Mauá, São Paulo State, Brazil.

\begin{tabular}{|c|c|c|c|c|c|c|c|c|c|c|c|c|}
\hline \multirow[t]{4}{*}{ Right side } & \multicolumn{12}{|c|}{ Left side } \\
\hline & \multicolumn{4}{|c|}{ Class 1} & \multicolumn{4}{|c|}{ Class 2} & \multicolumn{4}{|c|}{ Class 3} \\
\hline & \multicolumn{2}{|c|}{ Canine } & \multicolumn{2}{|c|}{ Molar } & \multicolumn{2}{|c|}{ Canine } & \multicolumn{2}{|c|}{ Molar } & \multicolumn{2}{|c|}{ Canine } & \multicolumn{2}{|c|}{ Molar } \\
\hline & $n$ & $\%$ & $\mathrm{n}$ & $\%$ & $n$ & $\%$ & $n$ & $\%$ & $n$ & $\%$ & $\mathrm{n}$ & $\%$ \\
\hline \multicolumn{13}{|l|}{ Females } \\
\hline \multicolumn{13}{|l|}{ Class 1} \\
\hline Canine & 132 & 97.8 & 129 & 95.5 & 1 & 0.7 & 2 & 1.5 & 2 & 1.5 & 4 & 3.0 \\
\hline Molar & 132 & 95.7 & 136 & 98.6 & 4 & 2.9 & 2 & 1.4 & 2 & 1.4 & - & - \\
\hline \multicolumn{13}{|l|}{ Class 2} \\
\hline Canine & 7 & 30.4 & 8 & 34.8 & 16 & 69.6 & 14 & 60.9 & - & - & 1 & 4.3 \\
\hline Molar & 4 & 23.5 & 2 & 11.8 & 13 & 76.5 & 14 & 82.4 & - & - & 1 & 5.9 \\
\hline \multicolumn{13}{|l|}{ Class 3} \\
\hline Canine & 4 & 50.0 & 4 & 50.0 & 1 & 12.5 & 1 & 12.5 & 3 & 37.5 & 3 & 37.5 \\
\hline Molar & 7 & 63.6 & 3 & 27.3 & 1 & 9.1 & 1 & 9.1 & 3 & 27.3 & 7 & 63.6 \\
\hline \multicolumn{13}{|l|}{ Males } \\
\hline \multicolumn{13}{|l|}{ Class 1} \\
\hline Canine & 133 & 94.3 & 127 & 90.0 & 5 & 3.5 & 7 & 5.0 & 3 & 2.1 & 7 & 5.0 \\
\hline Molar & 126 & 92.0 & 132 & 96.3 & 9 & 6.6 & 3 & 2.2 & 2 & 1.5 & 2 & 1.5 \\
\hline \multicolumn{13}{|l|}{ Class 2} \\
\hline Canine & 10 & 35.7 & 14 & 50.0 & 18 & 64.3 & 14 & 50.0 & - & - & - & - \\
\hline Molar & 11 & 44.0 & 8 & 32.0 & 14 & 56.0 & 17 & 68.0 & - & - & - & - \\
\hline \multicolumn{13}{|l|}{ Class 3} \\
\hline Canine & 3 & 33.3 & 2 & 22.2 & - & - & - & - & 6 & 66.7 & 7 & 77.8 \\
\hline Molar & 9 & 56.3 & 3 & 18.7 & - & - & 1 & 6.3 & 7 & 43.7 & 12 & 75.0 \\
\hline
\end{tabular}


$11 \%$, and $2.9 \%$, respectively. Confidence intervals (95\%) for the prevalence values of molar and canine relationships did not indicate statistically significant differences between molar and canine relationships.

Prevalence rates of unilateral and bilateral posterior crossbite were $10.5 \%$ and $0.8 \%$, respectively. Type I arches were found in approximately $80 \%$ of the sample in both upper and lower dental arches. Crowding was observed in 7.0\% (maxillary arch) and $11.3 \%$ (mandibular arch).

Overjet $>3 \mathrm{~mm}$ was registered in $16 \%$ (Figure 1), openbite in $27.9 \%$, and overbite $>3 \mathrm{~mm}$ in $7 \%$ of the preschool children (Figure 2).

\section{Discussion}

Epidemiological studies on malocclusion are important for the identification of changes in occlusion during growth and for understanding the distribution of oral health conditions in individuals and between different population groups 30 .

Cross-sectional studies help formulate hypotheses to deal with the main factors associated with malocclusion, but they have some limitations. Interpretation and direct comparison between the results should be done with caution.

Certain difficulties when attempting to describe and interpret data on malocclusion in the deciduous dentition have been reported: chil- dren with permanent teeth included in the sample; differences in measurement and tabulation of specific disorders; identification of cases and non-cases from an epidemiological perspective; definition of severe and mild cases from the perspective of public health rather than clinical orthodontics; and lack of an index to provide a meaningful score of occlusal conditions in the deciduous dentition as a whole.

A bilateral relationship of the second deciduous molars in straight terminal plane was recorded in $84.3 \%$ of the sub-sample 22 . The molar relationship in the deciduous dentition is considered one of the main factors influencing development of the permanent dentition, since it is capable of directing the path of eruption of the first permanent molars, oriented by distal surfaces on the second deciduous molars 1 . There is a consensus among specialists that a distal step of the second deciduous molars may develop into Angle Class 2 molar relationship in the permanent dentition 11,12,31,32,33. Similarly, a mesial step of the second deciduous molars seldom turns into a distal bite. In both cases, the relationship of the second deciduous molars appears to provide a fairly reliable prediction of future permanent molar relationship 11.

Prevalence of bilateral Class 1 canine relationship was $86 \%$. Despite the notion that canine is a more reliable indicator than molar relationship for determining intermaxillary re-

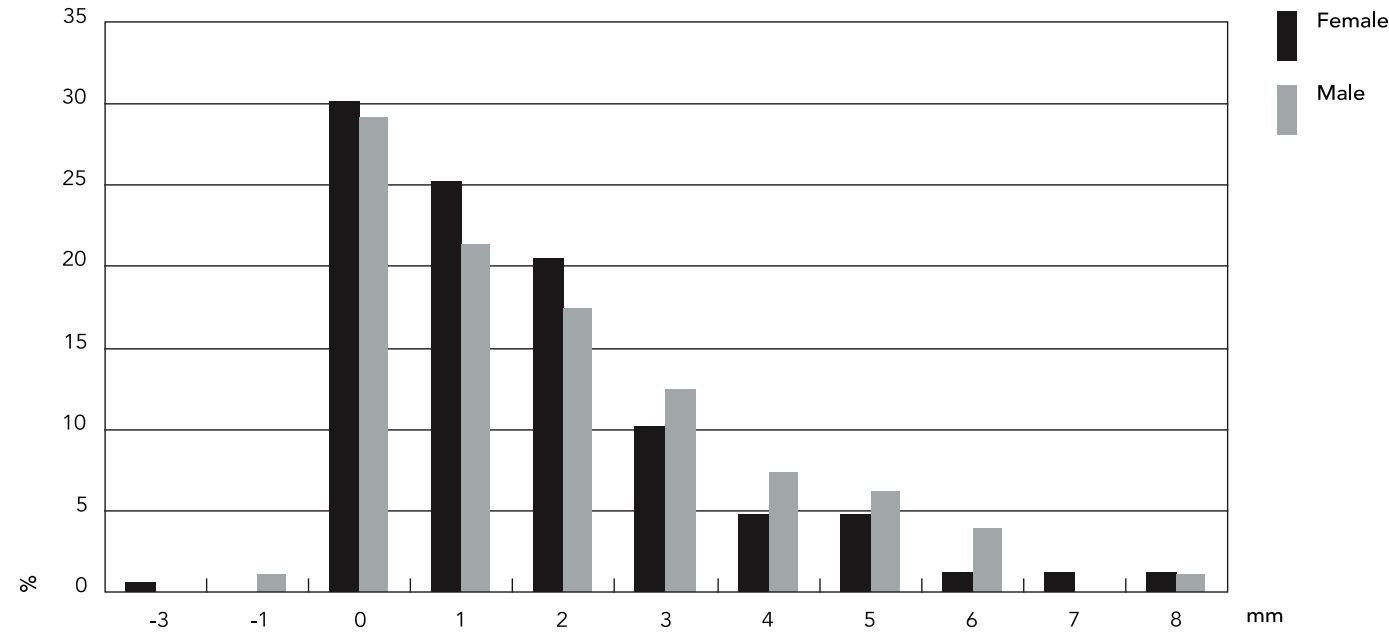




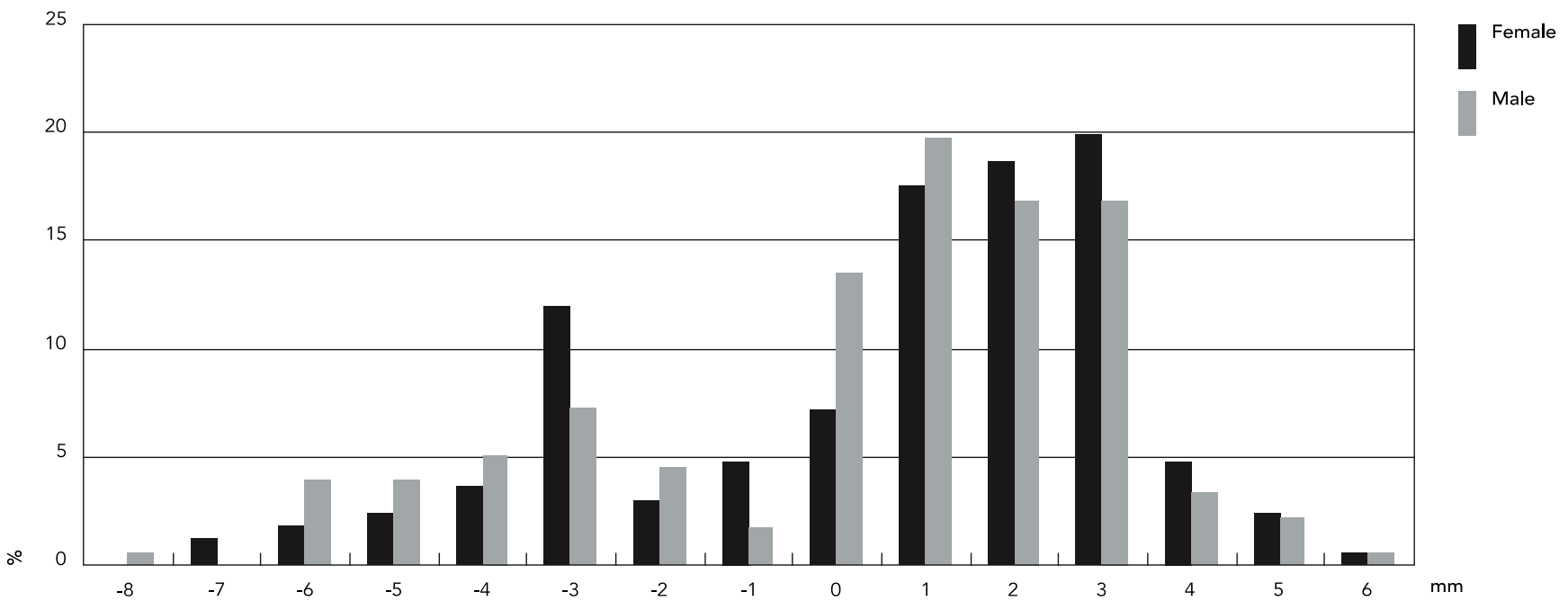

lationship 3,5,34, the results showed that bilateral molar and canine relationships were not significantly different. This result should be confirmed using further epidemiological studies, and the magnitude of sagittal relationship deviations should be more precisely measured.

Overjet and overbite adopted cut-off points described in the literature that allowed excluding cases of mild malocclusion. Overjet $>3 \mathrm{~mm}$ and overbite $>3 \mathrm{~mm}$ were recorded in $16 \%$ and $7 \%$ of the children, respectively. Attention should be given to the interpretation of these rates, considering that recent epidemiological studies have recognized prevalence rates of these occlusal conditions up to $3 \mathrm{~mm}$ as the standard of acceptability 5,9,13.

Deep overbite generally interferes in opening, protrusion, and lateral movements and is potentially hazardous to the temporomandibular joint when transferred to the permanent dentition ${ }^{35}$. A negative overbite (openbite) appears to be the only malocclusion expected to decrease in the transition to the permanent dentition 5 . This speaks in favor of investigation of the openbite magnitude and factors that could be associated with its occurrence in the deciduous dentition, in order to identify possible implications for the permanent dentition. Preventive strategies during childhood are indicated 9 .

Likewise, attention should be given to the posterior crossbite in the deciduous dentition.
Posterior crossbite is one of the most prevalent malocclusions in the deciduous and early mixed dentition 11. It is believed that a posterior crossbite is transferred from the deciduous to the permanent dentition 11,35, with long-term effects on the growth and development of the teeth and jaws, and even craniofacial asymmetry 10,11,36,37. Impaired nasal breathing caused by enlarged tonsils and adenoids 11,19 are also related to posterior crossbites, and can be diagnosed early.

An increasing trend in crowding when transferred from the deciduous to the permanent dentition and its consequences have been documented 10,38. However, some authors have failed to distinguish between absence of interdental spaces and crowding when describing their results $2,3,5,30,39$, making it difficult to compare results. Efforts in the assessment of crowding severity are also recommended.

The problem is complex and highlights the need to develop a standardized measurement for assessing the deciduous dentition, capable of: (1) defining a deviation from ideal occlusion that is severe enough to require orthodontic treatment, (2) quantifying the social and psychological impact of malocclusion during childhood, and (3) identifying the opinions of the family and child regarding the appearance and masticatory efficiency of the child's dentition.

These factors, analyzed together, would contribute to the development of an occlusal index. 
They might also allow the definition of cases and non-cases, an essential concept in epidemiological studies.

\section{Conclusions}

From a public health perspective, assessment of malocclusion in the deciduous dentition should focus on its magnitude and severity, crucial for efficiently targeting actions during childhood and preventing problems with occlusion later in life. Acknowledging that malocclusion cannot be considered a disease with a series of well-defined symptoms, standard methods for its evaluation should be adopted. Need for further improvement and consensus on the interpretation of epidemiological data is emphasized.

\section{Resumo}

Dados secundários de uma amostra aleatória de préescolares brasileiros foram analisados com o objetivo de avaliar a prevalência de desvios oclusais na dentição decídua, que podem adversamente afetar a dentição permanente, com base em critérios revisados. Overjet e overbite apresentaram pontos de corte descritos na literatura para a remoção dos casos de má oclusão leve. Overjet $>3 \mathrm{~mm}$ e overbite $>3 \mathrm{~mm}$ afetaram $16 \%$ e $7 \%$ das crianças, respectivamente. No plano sagital foram consideradas apenas as taxas de desvios bilaterais: relação molar em degrau distal $(9,7 \%) e$ mesial (6,0\%); relação dos caninos Classe 2 (11,0\%) $e$ Classe 3 (2,9\%). Para os demais desvios não foram relatados na literatura critérios de severidade. Valores brutos de mordida aberta anterior (27,9\%); mordida cruzada posterior (11,3\%); apinhamento dentário maxilar (7,0\%) e mandibular (11,3\%) foram registrados. A avaliação da má oclusão na dentição decídua deve considerar a severidade dos desvios para a identificação de casos e não-casos de relevância em saúde pública. Enfatiza-se a necessidade de maior consenso e melhora na interpretação de dados epidemiológicos sobre a má oclusão nesse estágio de desenvolvimento.

Oclusão Dentária; Dentição Primária; Saúde Bucal

\section{Contributions}

E. R. Almeida and P. Frazão planned the study, analyzed and interpreted the results, and wrote and revised the text. P. C. Narvai also planned the study, contributed to interpretation of the results, and revised the text. A. C. Guedes-Pinto revised the text. All four authors approved the final manuscript. 


\section{References}

1. Baume LJ. Physiological tooth migration and its significance for the development of occlusion. I. The biogenesis course of the deciduous dentition. J Dent Res 1950; 29:123-32.

2. Foster TD, Hamilton MC. Occlusion in the primary dentition: study of children at $2^{1 / 2}$ to 3 years of age. Br Dent J 1969; 126:76-81.

3. Ravn JJ. Occlusion in primary dentition in 3-yearold children. J Dent Res 1975; 83:123-30.

4. Nyström M. Occlusal changes in the deciduous dentition of a series of Finnish children. Proc Fin Dent Soc 1981; 77:288-95.

5. Tschill P, Bacon W, Sonko A. Malocclusion in the deciduous dentition of Caucasian children. Eur J Orthod 1997; 19:361-7.

6. Chiavaro A. Malocclusion of temporary teeth. Int J Orthod 1915; 1:171-9.

7. Frazão P, Narvai PC, Latorre MRDO, Castellanos RA. Are severe occlusal problems more frequent in permanent than deciduous dentition? Rev Saúde Pública 2004; 38:247-54.

8. Kabue MM, Moracha JK, Ng'ang'a PM. Malocclusion in children aged 3-6 years in Nairobi, Kenya. East Afr Med J 1995; 72:210-2.

9. Stahl F, Grabowski R. Orthodontic findings in the deciduous and early mixed dentition: inferences for a preventive strategy. J Orofac Orthop 2003; 64:401-6.

10. Keski-Nisula K, Lehto R, Lusa V, Keski-Nisula L, Varrela J. Occurrence of malocclusion and need of orthodontic treatment in early mixed dentition. Am J Orthod Dentofacial Orthop 2003; 124:631-8.

11. Petren S, Bondemark L, Soderfeldt B. A systematic review concerning early orthodontic treatment of unilateral posterior crossbite. Angle Orthod 2003; 73:588-96.

12. Baccetti T, Franchi L, McNamara Jr. JA, Tollaro I. Early dentofacial features of Class II malocclusion: a longitudinal study from the deciduous through the mixed dentition. Am J Orthod Dentofacial Orthop 1997; 111:502-9.

13. Di Nicoló R, Barbosa CS, McNamara JA, GuedesPinto AC. Desenvolvimento da sobressaliência nas dentaduras decídua, mista e permanente. Ortodontia 2002; 35:35-9.

14. Proffit WR, Fields HW. Contemporary orthodontics. 2nd Ed. Saint Louis: Mosby; 1993.

15. Katz CR, Rosenblatt A, Gondim PP. Nonnutritive sucking habits in Brazilian children: effects on deciduous dentition and relationship with facial morphology. Am J Orthod Dentofacial Orthop 2004; 126:53-7.

16. Charchut SW, Allred EN, Needleman HL. The effects of infant feeding patterns on the occlusion of the primary dentition. J Dent Child 2003; 70: 197-203.

17. Larsson E. Artificial sucking habits: etiology, prevalence and effect on occlusion. Int J Orofacial Myology 1994; 20:10-21.
18. Ogaard B, Larsson E, Lindsten R. The effect of sucking habits, cohort, sex, intercanine arch widths and breast or bottle feeding on posterior crossbite in Norwegian and Swedish 3-year-old-children. Am J Orthod Dentofac Orthod 1994; 106:161-6.

19. Venetikidou A. Incidence of malocclusion in asthmatic children. J Clin Ped Dent 1993; 17:89-94.

20. Kerosuo H. Occlusion in the primary and early mixed dentitions in a group of Tanzanian and Finnish children. ASDC J Dent Child 1990; 57:293-8.

21. Foster TD, Menezes DM. The assessment of occlusal features for public health planning purposes. Am J Orthod Dentofacial Orthop 1976; 69:83-90.

22. Almeida ER. Epidemiologia da oclusão dentária em pré-escolares do Município de Mauá, SP, Brasil, em 2001 [Masters Thesis]. São Paulo: Faculdade de Saúde Pública, Universidade de São Paulo; 2002.

23. Burt BA, Eklund SA. Dentistry, dental practice and the community. Philadelphia: WB Saunders; 1999.

24. Pritchard DJ. Plasticity in early development. In: Mascie-Taylor CGN, Bogin B, editors. Human variability and plasticity. Cambridge: Cambridge University Press; 1995. p. 18-45.

25. Sheiham A, Spencer J. Health needs assessment. In: Pine CM, editor. Community oral health. London: Wright; 2002. p. 39-54.

26. Lwanga SK, Lemeshow S. Sample size determination in health studies: a pratical manual. Geneva: World Health Organization; 1991.

27. Kish L. Survey sampling. New York: John Wiley and Sons; 1965.

28. World Health Organization. Oral health surveys: basic methods. $4^{\text {th }}$ Ed. Geneva: World Health Organization; 1997.

29. Cohen JA. Coefficient of agreement for nominal scales. Educ Psychol Meas 1960; 20:37-46.

30. Otuyemi OD, Jones SP. Methods of assessing and grading malocclusion: a review. Aust Orthod J 1995; 14:21-7.

31. Ravn JJ. Longitudinal study of occlusion in the primary dentition in 3-and 7-year-old children. Scand J Dent Res 1980; 88:165-70.

32. Bishara SE, Hoppens BJ, Jakobsen JR, Kohout FJ. Changes in the molar relationship between deciduous and permanent dentitions: a longitudinal study. Am J Orthod Dentofacial Orthop 1988; 93:19-28.

33. Nanda RS, Khan I, Anand R. Age changes in the occlusal pattern of deciduous dentition. J Dent Res 1973; 52:221-4.

34. Silva Filho OG, Silva PRB, Rego MVNN, Silva FPL, Cavassan AO. Epidemiologia da má oclusão na dentadura decídua. Ortodontia 2002; 5:22-33.

35. Di Nicoló R, McNamara JA, Guedes-Pinto AC, Barbosa CS. Desenvolvimento da sobremordida nas dentições decídua, mista e permanente. J Bras Ortod Ortop Facial 2001; 6:31-4.

36. McNamara JA. Early intervention in the transverse dimension: is it worth the effort? Am J Orthod Dentofacial Orthop 2002; 121:572-4. 
37. Kurol J, Berglund L. Longitudinal study and costbenefit of the effect of early treatment of posterior cross-bites in the primary dentition. Eur J Orthod 1992; 14:173-9.

38. Warren JJ, Bishara SE, Yonezu T. Tooth size-arch length relationships in the deciduous dentition: a comparison between contemporary and historical samples. Am J Dentofacial Orthop 2003; 123:614-9.
39. Abu Alhaija ES, Qudeimat MA. Occlusion and tooth/arch dimensions in the primary dentition of preschool Jordanian children. Int J Paediatr Dent 2003; 13:230-9.

Submitted on $07 /$ Nov/2006

Final version resubmitted on 28/Jun/2007

Approved on 05/Sep/2007 